\title{
Research
}

\section{Habitat Scale Mapping of Fisheries Ecosystem Service Values in Estuaries}

\author{
$\underline{\text { Timothy G. O'Higgins }}^{1}$, Steven P. Ferraro ${ }^{2}$, Darrin D. Dantin ${ }^{2}$, Steve J. Jordan ${ }^{2}$, and \\ Marnita M. Chintala ${ }^{2}$
}

\begin{abstract}
Little is known about the variability of ecosystem service values at spatial scales most relevant to local decision makers. Competing definitions of ecosystem services, the paucity of ecological and economic information, and the lack of standardization in methodology are major obstacles to applying the ecosystem-services approach at the estuary scale. We present a standardized method that combines habitat maps and habitat-faunal associations to estimate ecosystem service values for recreational and commercial fisheries in estuaries. Three case studies in estuaries on the U.S. west coast (Yaquina Bay, Oregon), east coast (Lagoon Pond, Massachusetts), and the Gulf of Mexico (Weeks Bay, Alabama) are presented to illustrate our method's rigor and limitations using available data. The resulting spatially explicit maps of fisheries ecosystem service values show within and between estuary variations in the value of estuarine habitat types that can be used to make better informed resource-management decisions.
\end{abstract}

Key Words: ecosystem services; estuary; habitat; mapping; valuation

\section{INTRODUCTION}

Ecosystem services are the benefits obtained by humans from the environment (Millennium Ecosystem Assessment 2005). Estuaries provide many benefits to humans. They are sources of food, regulate water supply and nutrients, provide habitat for plants and animals, help prevent flooding, and are sites for recreation and other cultural activities (Costanza 1997, Wilson et al. 2005). The first human civilizations began beside estuaries about 8,000 years ago (Kennett and Kennett 2006). Coastal locations may even have played a role in our evolutionary development (Hardy 1960, Horrobin 2001, Verhaegen et al. 2002, 2007). It is not surprising, then, that estuaries are thought to be among the most valuable of any habitat type (Costanza et al. 1997). Today, many of the world's largest urban areas are situated around estuaries. Of the 32 largest cities in the world, 22 are co-located with estuaries (Ross 1995). On a global basis, coastal areas account for $61 \%$ of the world's population, and $71 \%$ of the world's coastal people live within $50 \mathrm{~km}$ of an estuary (Agardy et al. 2005). Human usage has impacted $>90 \%$ of formerly important species, destroyed $>65 \%$ of seagrass and wetland habitat, degraded water quality, and accelerated species invasion in estuaries (Lotze et al. 2006). The effects of global development and human population growth have greatly altered many estuaries from their natural state through destruction of wetland habitats (Millennium Ecosystem Assessment 2005, Lotze et al. 2006), introduction of toxic pollutants (e.g., Davis et al. 2007, Fleagle et al. 2007), elevation of nutrient inputs (Howarth 1998, Bricker et al. 2007), and alterations of water flow (Nilsson et al. 2005). Naturally functioning ecosystems are becoming increasingly scarce, and pristine estuarine systems may no longer exist (Conley 1999). These pressures have resulted in a reduction of estuarine quality and the capacity of estuaries to provide the benefits on which humans rely.

Economics and ecology do not function in isolation. Human development occurs within, and is an integral part of, the broader global ecosystem (Daily 1997, Daily and Walker 2000, Boumans et al. 2002, Ehrlich and Ehrlich 2008). Failure to account for the value of the services provided by ecosystems, and the fact that most causes of ecological damage are economic externalities, has resulted in a lack of 
effective policies to deal with ecological destruction and contributed to the decline of estuarine habitats. As a result, it is now clear that people must recognize the benefits obtained by humans from ecosystems (Millennium Ecosystem Assessment 2005) to account for the ecological costs of our actions and the tradeoffs involved in development decisions (Wallace 2007). The science of ecological economics is gaining increasing attention in academia, in government policy (European Union 2008), from major corporations (Bishop et al. 2008), and from nongovernmental organizations (Nelson et al. 2009). A growing number of studies have estimated economic values for various estuarine ecosystems (e.g., Johnston et al. 2002, Hazen and Sawyer 2008, Kroeger and McMurray 2008), yet there are still considerable theoretical and practical challenges to applications of the ecosystem-services approach that require novel ideas from economists and ecologists (Daily and Ehrlich 1999).

It is convenient to create a typology of ecosystem services to quantify the benefits provided by ecosystems. A widely accepted typology is that of the Millennium Ecosystem Assessment (MEA; 2003), which recognizes four types of services:

1. Provisioning services, including the production of food, fiber, and freshwater.

2. Regulating services such as climate regulation, and air-quality regulation.

3. Cultural services, including the spiritual, religious, aesthetic, and educational values of nature.

4. Supporting services, such as nutrient cycling, photosynthesis, and refugia functions.

In the ecosystem-services framework based on the MEA typology, the sum of these four types of services measured as Economic Values (EV) is the Total Economic Value (TEV) of an ecosystem. However, the MEA ecosystem-services typology is not universally accepted. Boyd and Banzhaf (2007) and Wallace (2007) have pointed out the danger of confusing "means" and "ends," which can lead to "double counting." For example, the distinction between the refugia function of an eelgrass (Zostera marina) bed, a supporting service, as a "means" toward the "end" of commercial fishing, a provisioning service, is not explicit in the MEA typology. Thus, economic valuation of both refugium and fisheries values would constitute double counting. To address the potential for double counting in the MEA approach, Boyd and Banzhaf (2007) propose a framework based on "final services," defined as "those components of nature directly used or enjoyed by humans." They argue that taking inventory of stocks of ecosystem components is a more legitimate approach to valuation, and that recreational services are not ecosystem services, but benefits to which ecosystems provide inputs. However, the interconnectedness of ecosystem components and processes means that there is not always a clear distinction between means and ends (Costanza 2008). To some degree, the choice of typology may depend on the scope of particular study or the spatial scale under consideration (Costanza 2008, Fisher and Turner 2008). Here, we focus on recreationaland commercial-use values. Recreational use measures an end value that reflects various intermediate services and can be achieved through various means.

Of the four MEA service categories, generally only provisioning services have market values. Although markets are developing for some other services, e.g., carbon storage (Nordhaus 2008), most remain outside the economic framework and, some, such as religious and spiritual functions of nature, lie beyond the scope of economic enquiry (Norgaard et al. 1998). Values for ecosystem services that do not have markets are measured using nonmarketvaluation techniques (see Champ et al. 2003 for a review). These methods generally measure consumer surplus, that is, the amount individuals would be willing to pay for a given good or service in addition to what they already spend to obtain that good (Marshall 1890). Similarly, producer surplus is the benefit producers of a good receive over and above the amount the costs incurred to produce that good.

The lack of markets for many ecosystem services is a major obstacle to comprehensive economic evaluations of estuaries (Pendleton et al. 2007). Wilson et al. (2005) identified 242 potentially valuable ecosystem goods and services from 23 coastal landscape features and habitats. Of these, only 33 had published economic values. As a result, the reliability of benefits transfer, i.e., using measured values from one study site and transferring them to another, is difficult to apply in coastal areas where the paucity of data can lead to unreliable results. Nevertheless, in the absence of 
site-specific primary studies, benefits transfer is commonly employed (e.g., Costanza et al. 1997, Troy and Wilson 2006). Benefit transfer is generally conducted in one of two ways: (1) direct transfer of a value from a study in a site similar to the site being studied, or (2) the use of meta-analysis, where a statistical model of valuation studies with different characteristics is used to predict a value for the site being studied. In an extensive meta-analysis of wetland valuation literature, Woodward and Wui (2001) conclude that the use of benefits transfer of wetland values based on previous studies is an imprecise science and stress the need for sitespecific studies. In a more recent analysis, Brander et al. (2006) state that the average error in value transfer for wetland studies using meta-analysis is $74 \%$. However, where primary data are not available, benefit transfer often represents the best available option.

Spatially explicit studies of ecosystem service values have extensively employed benefits transfer. These studies have been at coarse spatial scales covering large geographic areas (Costanza et al. 1997, Troy and Wilson 2006). For example, Costanza et al. used a global land-cover use dataset with $1^{\circ}$ latitude $\mathrm{x} 1^{\circ}$ longitude spatial resolution. In practice, most land-development and resourcemanagement decisions are made at the local level where information is needed at much finer spatial scales. This requires spatially differentiating EV within the geographic domain of interest; such finescale mapping of ecosystem services has received little attention and as such requires innovative new methods. Estuarine ecosystems are typically comprised of several habitat types such as emergent marshes, and vegetated and unvegetated intertidal and subtidal habitats. These habitats exhibit differing physical, biological, and chemical properties and processes and, thus, have different ecological values. The complexity of habitat structure determines the diversity and composition of organisms occurring (Hosack et al. 2006). The estuarine nursery concept now recognizes that specific habitats within estuaries can be of greater importance to juvenile fish (Dahlgren et al. 2006). Habitats containing complex structures such as eelgrass beds, emergent marsh, oyster (Ostreidae) reefs, or cobble, may provide refuge for juveniles of species (Amaral et al. 2009, Franca et al. 2009) and some habitats may provide increased prey availability (Holsman et al. 2006, Wouters and
Cabral 2009). Different estuarine habitats support different faunal communities over relatively small spatial scales (Hemminga and Duarte 2000, Jackson et al. 2001, Ferraro and Cole 2004). Furthermore, the faunal-habitat associations may be consistent in relative terms despite climatic and environmental variability (Ferraro and Cole 2007). As such, habitats may be considered as individual subsystems within the larger estuarine ecosystems, and their differing ecological values likely support differing economic value. Thus, because of their functionally discrete physical and biological properties, certain habitat templates may serve as sensible and useful ecological units upon which to estimate EV, and by their summation, TEV, for all or selected portions of estuaries.

With increasing emphasis on including valuation in natural-sciences research to aid with decision making, there is a necessity to develop rigorous and widely applicable methods to capture the spatial variability in ecosystem-services supply. Here, we present the results of a pilot project examining the feasibility of using a habitat-template approach, and existing data to map the distribution of recreational and commercial fisheries ecosystem service values in estuaries. The aim of this fine-scale mapping of ecosystem service values is to allow local decision makers to make better informed decisions involving tradeoffs in projects where changes in the area of estuarine habitat types are likely to occur. We present a testable model for fine-scale mapping of ecosystem services. The goal of the approach was to generate spatially explicit valuation estimates on the spatial scales of habitats within estuaries. We applied the method to three case-study estuaries. Using existing data, we estimated the value of consumer and producer surplus of the major recreational and commercial fisheries in each estuary. Recreational-use values capture values of a whole bundle of services as defined by the MEA, including services from all four MEA categories and, as such, are a useful, practical way of evaluating ecosystem-service supply. We applied a simple additive model to assign values per unit area to different habitat types within each estuary, based on existing maps and habitat-fauna relationships. The results are presented in the context of the MEA (2005) ecosystem service as well as the Boyd and Banzhaf (2007) final services framework. 


\section{METHODS}

Our three case-study sites are on the U.S. west coast (Yaquina Bay, Oregon), Gulf coast (Weeks Bay, Alabama), and east coast (Lagoon Pond, Massachusetts) (Fig. 1). Here, we outline the general methodology for economic evaluation and mapping as well as specific details of the methods as they applied to each estuary.

Yaquina Bay $\left(44^{\circ} 36^{\prime} \mathrm{N}, 124^{\circ} \mathrm{W}\right)$ is a macrotidal estuary flowing into the Pacific Ocean at Newport, Oregon. The bay lies at the mouth of the Yaquina River and has a predominantly forested watershed of $655 \mathrm{~km}^{2}$ (Sigleo and Frick 2007). The estuary covers an area of $\sim 18 \mathrm{~km}^{2}$, of which $40 \%$ is subtidal channel and $60 \%$ is intertidal flats and marshes. Yaquina Bay is a well-studied estuary. A recently compiled bibliography (Webster and Hiveley 2006) contains 1,244 articles relating to the estuary. Yaquina Bay is strongly influenced by oceanographic conditions, including annual and super-annual cycles in climate and upwelling (Hickey and Banas 2003). The estuary receives large loads of nutrients, predominantly from the marine end, and is not thought to be eutrophied (Sigleo et al. 2005, Brown and Ozretich 2009).

The Yaquina estuary has supported subsistence fisheries for at least two millennia (Tveskov and Erlandson 2003). Since European settlement, and until fairly recently, the principal local economic activity has been natural-resource extraction. However, recent natural-resource declines have shifted the local economy to an increased dependence on tourism (Huppert et al. 2003). Tourism is largely centered around recreational outdoor activities including fishing, crabbing, and clamming (Parrish and Litle 2001). The most important local commercial fishery is for Dungeness crab (Cancer magister).

Weeks Bay, Alabama, in the northern Gulf of Mexico $\left(30^{\circ} 45^{\prime} \mathrm{N}, 87^{\circ} 88^{\prime} \mathrm{W}\right)$, is a subestuary of Mobile Bay (Stutes et al. 2006). Its surface area is $\sim 8 \mathrm{~km}^{2}$. The Weeks Bay watershed covers about $512 \mathrm{~km}^{2}$. The bay experiences slightly elevated nutrient concentrations relative to similar systems, possibly because of its largely agricultural watershed (Cebrian and Valiela 1999). Salinity in the bay is primarily controlled by freshwater flow from two river discharges and from tidal exchange with Mobile Bay (Shroeder et al. 1990, 1992). Weeks Bay is designated as a National Estuarine Sanctuary and receives additional protection because of its classification as a National Estuarine Research Reserve. The natural shoreline is fringed by a combination of salt marsh, forested wetland, and beach. Shoreline alteration is minimal and mostly restricted to dock structures within pockets of residential development along the southeast, southwest, and northeast shores.

Lagoon Pond, Massachusetts (41 ${ }^{\circ} 26^{\prime} \mathrm{N}, 70^{\circ} 35^{\prime}$ W) lies on the northern shore of Martha's Vineyard, between the towns of Oak Bluffs and Tisbury. The pond is $2.1 \mathrm{~km}^{2}$ in area, with a watershed of 15.6 $\mathrm{km}^{2}$. The pond receives nitrogen loadings both from acid rain and the surrounding land use (Gaines 1986). Mean depth at low water is $2.83 \mathrm{~m}$, with a tidal range of $0.53 \mathrm{~m}$. The pond supports a recreational and small commercial shellfish industry for bay scallops (Argopecten irradians), quahog (Mercenaria mercenaria), and soft-shell clam (Mya arenaria). Shellfish in the pond are actively managed by the Martha's Vineyard Shellfish Group. The towns of Oak Bluffs and Tisbury conduct municipal aquaculture programs (Carman et al. 2009), including seeding of bay scallops and quahogs, as well as culturing the seed shellfish through their first growing season and their release into the wild in the fall of each year. Traditionally the bay scallop fishery provided an important but highly variable source of income to local fishermen. Bay scallop fisheries throughout Massachusetts reached a peak in the mid 1950s, and have since been in general decline (McFarlane 1999).

The goal of our methodology was to render economic value in spatially explicit format on the scale of individual habitat types using ecological data, to assess the feasibility and utility of fine-scale ecosystem-services mapping. The method required three types of data: (1) economic data, (2) geographical data, and (3) biological data. Figure 2 shows a conceptual diagram of information flow required to construct our economic-value maps. Table 1 summarizes the fisheries valued, the methods used for valuation and mapping, and the habitats valued for each estuary. Specific details of the methodology used in each estuary are presented below. 
Fig. 1. (A) Location of the three estuarine study sites showing one on each coast of the conterminous U. S. (B) Lagoon Pond, Martha's Vineyard, showing location of eelgrass habitat. (C) Yaquina Bay, Oregon, showing emergent marsh, mudflat, and eelgrass habitats. (D) Weeks Bay, Alabama, showing emergent marsh habitat.

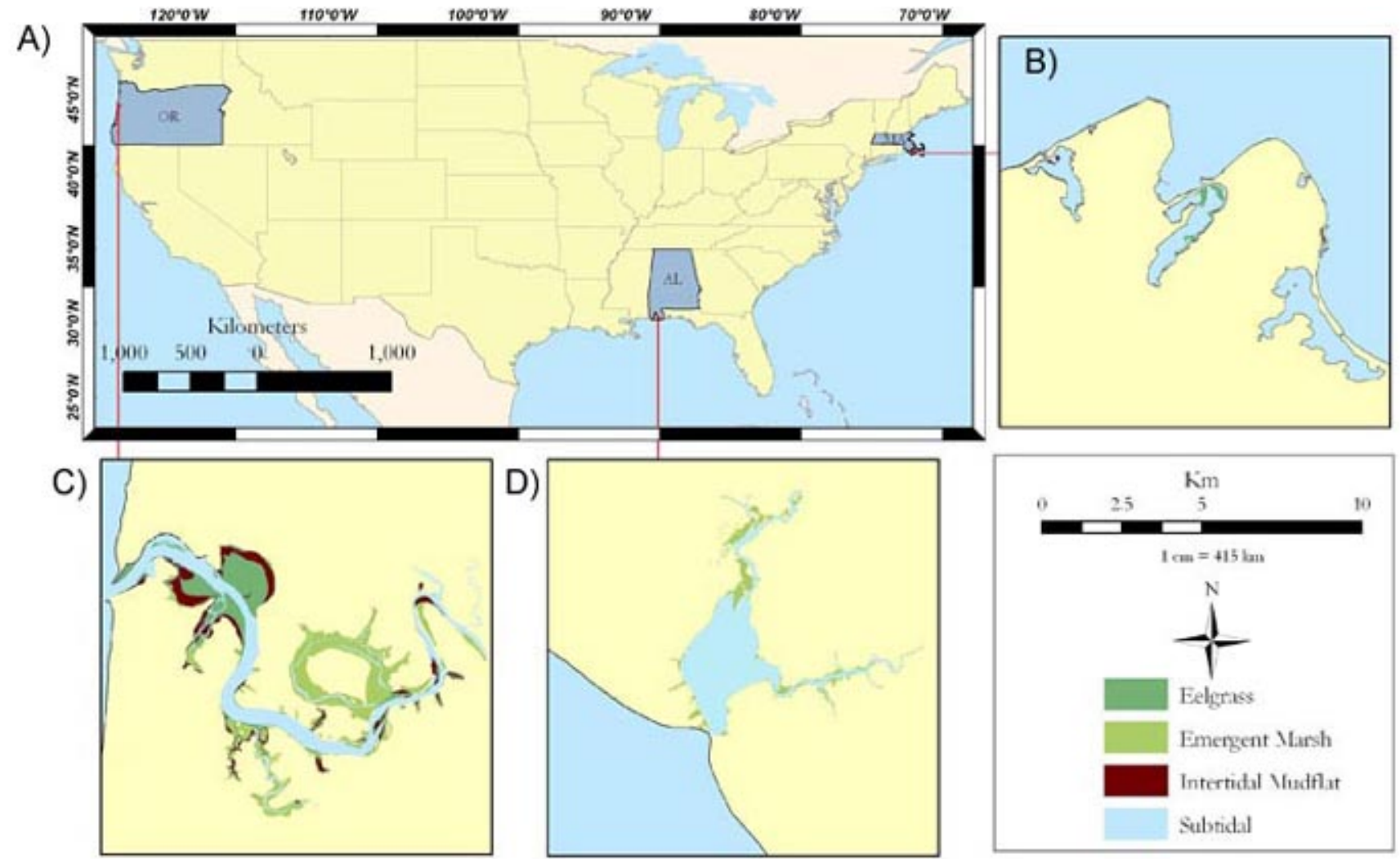

Note: Maps of each estuary are at the same scale.

\section{Valuation}

The scope of our work was limited to the recreational and commercial fishing-services values of specific fisheries and estuarine habitats. Recreational value was measured as consumer surplus, and commercial value was measured as producer surplus. Recreational and Commercial Fishing Value (RCFV) was estimated as the sum of the recreational and commercial values. Economic valuation was conducted through an extensive literature review and data-mining exercise. Original, site-specific data were used preferentially. If no site-specific data were available, benefitstransfer techniques were employed. All prices were converted to 2007 dollars using the Consumer Price Index $(\mathrm{CPI})$.
Generally, to evaluate recreational fisheries, two distinct types of data were required: (1) Willingness to Pay (WTP), and (2) fishing-effort data. Willingness To Pay for a given fishery, that is, consumer surplus, was reported in existing literature in two formats: WTP per fishing trip, or WTP per local household. For the former, it was also necessary to obtain estimates of Number of Individuals (NOI) fishing; for the latter, census data were used. Estimates of the NOI fishing for a species at a given location were obtained by personal communication or from unpublished data. Where no figure was available for a particular site, the NOI was estimated using an existing meta-analysis (Loomis and Richardson 2007). The value of commercial fisheries was estimated by combining ex-vessel value data from the National Oceanic and 
Fig. 2. Schematic diagram showing the types of data required to render economic values spatially explicit using the simple additive model along with the equation used to unite the three different kinds of data.

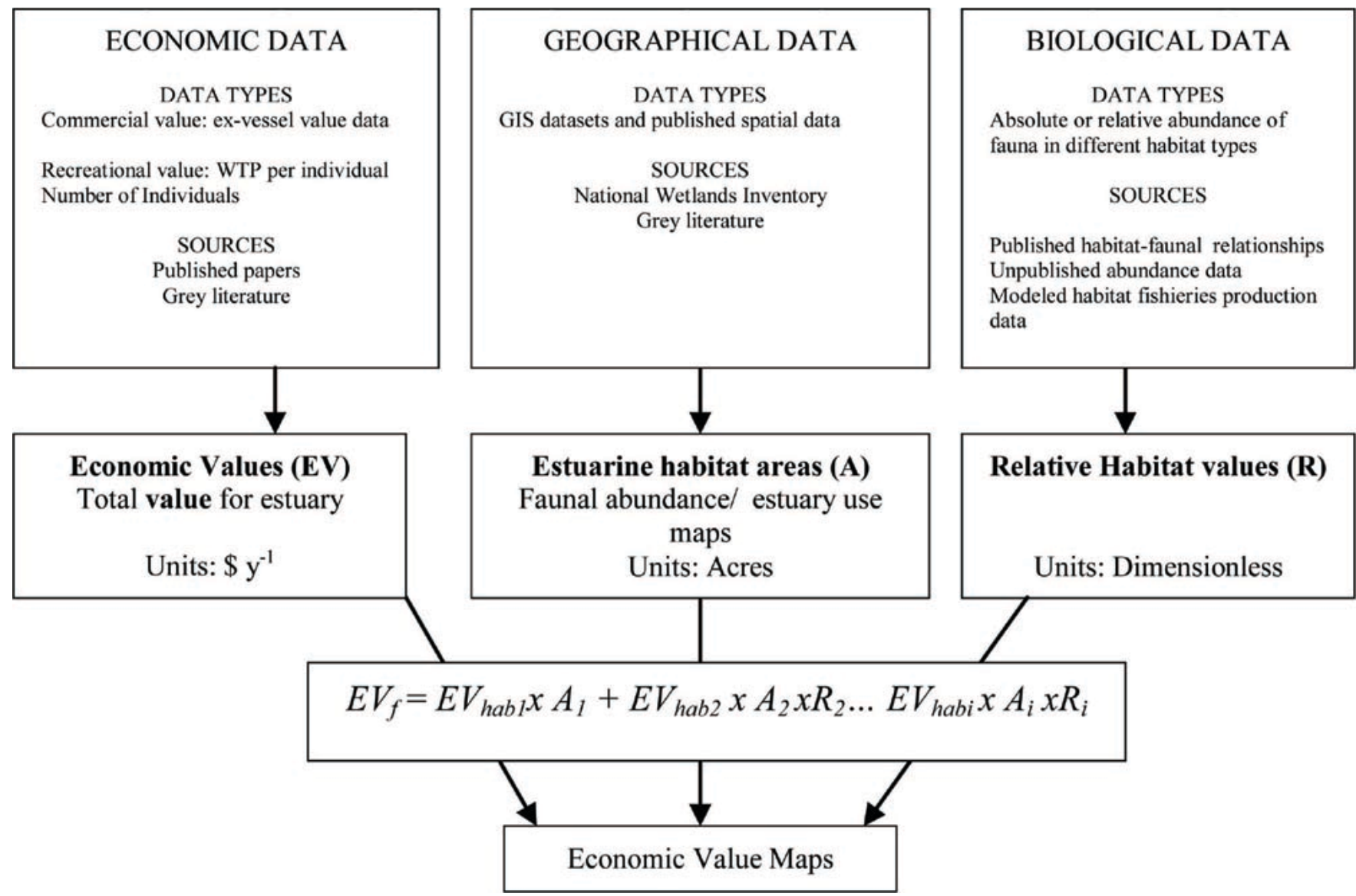

Note: $E V_{f}=$ economic value of a specific fishery $\left(\$ / \mathrm{y}^{-1}\right) ; E V_{\text {habl } \ldots i}=$ economic value of the specific habitat types $\left(\$ /\right.$ acre $\left./ /^{-1} / \mathrm{y}^{-1}\right) ; R_{2 . . . i}=$ values of habitat types relative to the value of the first habitat type (dimensionless).

Atmospheric Administration Fisheries Service (NOAA) with information on the catch in each estuary. Producer surplus, i.e., the value of the commercial fishery over and above the costs incurred to operate the fishery, was assumed to be $25 \%$ of ex-vessel value (G. Sylvia, personal communication). Stock values (sensu Boyd and Banzahf 2007) were calculated as ex-vessel values.

Error: qualitative estimates of confidence ("low/ high") for recreational fisheries estimates were made on WTP and NOI for each valuation. For WTP, "high" confidence was assigned if the figure used was site-specific. Non-site or activity-specific estimates were assigned "low" confidence. Similarly, direct measurements of NOI were assigned high confidence, whereas personal communications and values predicted from metaanalysis were assigned low confidence. For commercial fisheries where multiple-year fisheries datasets were available, standard error was calculated and expressed as a percentage. Commercial fisheries values obtained from models were assigned low confidence. It was not possible to quantitatively assess errors in the summed recreational and commercial estimates, as no 
Table 1. Summary of the fisheries evaluated, type of fishery ( $\mathrm{R}=$ recreational, $\mathrm{C}=$ commercial), use of benefit transfer for recreational valuation ( $\mathrm{Y}=\mathrm{yes}, \mathrm{N}=\mathrm{no}$ ), mapping method, and habitat types occurring in each estuary.

\begin{tabular}{|c|c|c|c|c|c|}
\hline Estuary & Fisheries & Type & $\begin{array}{l}\text { Benefit } \\
\text { transfer }\end{array}$ & $\begin{array}{l}\text { Mapping } \\
\text { method }\end{array}$ & Habitats \\
\hline \multirow{4}{*}{ Yaquina Bay } & salmon & $\mathrm{R}, \mathrm{C}$ & $\mathrm{Y}$ & - & \multirow{4}{*}{$\begin{array}{l}\text { subtidal } \\
\text { intertidal } \\
\text { eelgrass }\end{array}$} \\
\hline & Dungeness crab & $\mathrm{R}, \mathrm{C}$ & $\mathrm{N}$ & 2 & \\
\hline & bay clams & $\mathrm{R}$ & $\mathrm{Y}$ & 1 & \\
\hline & oyster & $\mathrm{C}$ & - & 1 & \\
\hline \multirow[t]{2}{*}{ Lagoon Pond } & bay scallops & $\mathrm{R}, \mathrm{C}$ & $\mathrm{Y}$ & 2 & $\begin{array}{l}0-1 \mathrm{~m} \text { deep } \\
1-2 \mathrm{~m} \text { deep } \\
2-3 \mathrm{~m} \text { deep } \\
>3 \mathrm{~m} \text { deep }\end{array}$ \\
\hline & spotted trout & $\mathrm{R}$ & $\mathrm{Y}$ & 2 & \multirow{3}{*}{$\begin{array}{l}\text { Juncus } \\
\text { Spartina } \\
\text { unvegetated }\end{array}$} \\
\hline \multirow[t]{2}{*}{ Weeks Bay } & red drum & $\mathrm{R}$ & $\mathrm{Y}$ & 2 & \\
\hline & blue crab & $\mathrm{C}$ & - & 2 & \\
\hline
\end{tabular}

quantitative errors were available for the recreational data.

\section{Yaquina Bay}

A variety of techniques were required to carry out the valuation exercise in Yaquina Bay. Multiyear economic commercial-fisheries data were available for the oyster (United States Department of Agriculture 2008) and within-estuary crab fisheries (Oregon Department of Fish and Wildlife, unpublished data). Local multiyear salmon-fishery estimates by weight were available (Oregon Department of Fish and Wildlife, unpublished data) and were converted to estimates of value according to Hanna et al. (2006). The offshore recreational and commercial salmon fisheries were reported for the Yaquina Bay area; it is uncertain what proportion of the local ocean catch is supported by the Yaquina River and its estuary. Thus, maximum and minimum estimates were made based on the assumption that all (maximum) or none (minimum) of the ocean-caught salmon were dependent on the Yaquina estuary. The value of the Yaquina estuary contribution to the ocean commercial crab fishery was taken from a published model (Armstrong et al. 2003).

Fewer data were available for the value of the recreational fisheries within the estuary. Benefits transfer was used to estimate recreational WTP for Oregon salmon (Hanna et al. 2006) and clam fisheries (Carlson and Fujimoto 2001). Recreational WTP for salmon fisheries in Oregon has been the subject of considerable literature (see Richardson and Loomis 2009), and an estuary-specific WTP figure was combined with estimates of recreational effort (Robert Buckman, personal communication). Current estimates of recreational clamming effort were obtained from the Oregon Department of Fish and Wildlife (Ainsworth, personal communication). For the recreational Dungeness crab fishery, zipcode data for recreational crabbers were obtained from the Oregon Department of Fish and Wildlife and used to construct a simple Travel Cost Model (TCM) using straight-line distances from zip code to zip code, and conservative assumptions about gas prices and the value of time to estimate consumer 
surplus. Current estimates of recreational crabbing effort were also obtained from the Oregon Department of Fish and Wildlife (Ainsworth, personal communication).

Because of the lack of information on recreational WTP for clamming in Yaquina Bay, we used Carlson and Fujimoto's (2001) general beachrecreation value for clamming. For comparison, we also estimated the value of clam stocks within the bay. Published clam densities (Hancock et al. 1979) were converted to estimates of weight using data from Griffin (1995), and weights were converted to EV using ex-vessel values from Endreny and Sylvia (2006).

\section{Lagoon Pond}

Multiyear primary data for the annual commercial scallop landings in the pond were supplied by the local shellfish constable (Grunden, personal communication). These were combined with annual average values per weight to give an estimate of the commercial value of the scallop fishery.

No primary economic data were available for the recreational scallop fishery, so benefits transfer was used. A contingent valuation model for shellfisheries in Upper Narragansett Bay was used for the benefit transfer (Hayes et al. 1992). We used a logit model based on 1983 median Willingness To Pay (WTP) per household for the opportunity of continued shellfisheries, including both a use and nonuse value. Household income was the determining variable for WTP. To apply the model to modern-day Massachusetts, current medianincome values for households in Martha's Vineyard were back-calculated to 1983 values using the Consumer Price Index (CPI). These values were then applied to the model and the resulting median WTP were recalculated to 2007 values, again using the CPI (Table 2).

\section{Weeks Bay}

As no direct estimates of recreational fishing effort were available for Weeks Bay, we estimated it indirectly using Loomis and Richardson's (2007) meta-analysis benefit-transfer calculator, using input data on the area of the Weeks Bay National Estuarine Research Reserve and the median income of the surrounding counties. The entire recreational WTP value was attributed to spotted sea trout (Cynoscion nebulosus) and red drum (Sciaenops ocellatus) which, combined, make up $>95 \%$ of recreational fisheries in the bay (Phipps, personal communication). The commercial value of the blue crab (Callinectes sapidus) fishery in Weeks Bay was estimated using the habitat-based model of blue crab fishery production used by Jordan et al. (2009).

\section{Mapping}

Base layers for habitat distribution were taken from the National Wetlands Inventory (NWI), and habitats not represented in the NWI were inputted to GIS by georeferencing to the NWI data using ArcGIS 9.3. Areas for georeferenced features were calculated from the resulting GIS layers.

Habitat-usage values were calculated in one of two ways, depending on the data available:

Method 1: In cases where surveys of recreational fishery activity in given estuarine areas had been conducted, or where commercial production of a given species was confined entirely to a single area, the proportion of the total value for the fishery occurring in each particular area was known. In these cases it was possible to divide the value of the fishery in a particular habitat by the area of the habitat to get the values per unit area. These values were then assigned to the relevant GIS layers.

Method 2: In most cases the proportion of a given fishery in a given habitat type was not known. Relative faunal-usage values for habitats were taken from published sources when available (e.g., Holsman et al. 2006, Jordan et al. 2009), and from primary ecological-research studies conducted by the U.S. Environmental Protection Agency (EPA; unpublished data). When no habitat-specific information was available for a fishery, all habitats were assumed to have equal value.

The relative faunal-usage values described above were combined with habitat areas from GIS economic values from the valuation study to calculate the economic value of individual habitat types using the following formula:

Equation 1: $E V_{f}=E V_{h a b 1} x A_{1}+E V_{h a b 2} x A_{2} x R_{2} \ldots$ $E V_{h a b i} \times A_{i} \times R_{i}$

Where $E V_{f}$ is the economic value of commercial and recreational fishery for a single species (in $\$ / y^{-1}$ ), $E V_{\text {habl }}$ to $E V_{\text {habi }}$ are the values of each habitat type to that fishery, and $A_{1}$ to $A_{i}$ are the areas of each 
Table 2. Number of households and median income used to model willingness to pay for access to recreational shellfisheries in Lagoon Pond, Martha's Vineyard.

\begin{tabular}{lcccc}
\hline \hline & Number of households & Median income $\dagger$ & Predicted median bid $\dagger$ & Willingness to Pay $\dagger$ \\
\hline Vineyard Haven & 941 & 46,444 & 253 & 238,487 \\
Oak Bluffs & 1,590 & 52,326 & 285 & 453,738 \\
Edgartown & 1,582 & 62,734 & 343 & 543,006 \\
West Tisbury & 1,034 & 67,302 & 369 & 381,732 \\
& & & & \\
& & & Total & $1,616,963$ \\
\hline
\end{tabular}

$† \$ U . S ., 2007$

habitat type estimated using GIS. $E V_{f}$ was estimated through the economic-valuation process. The value for each habitat type was set relative to the first habitat type $\left(E V_{\text {habl }}\right)$ using the relative values $\left(R_{1}\right.$ to $R_{i}$ ) obtained from original studies and from literature. Because the areas of each habitat type and the total value $\left(E V_{f}\right)$ of the habitats contributing to the fishery were known from the valuation process, it was possible to rewrite the equation to solve for $E V_{h a b l}$ and substitute this value to solve for the remaining habitat values. The economic values of the individual fisheries layers were summed spatially using ArcGIS 9.3 to yield RCFV per unit area. Where spatial distribution of value was mapped directly, mean habitat values for individual habitat types were taken by random sampling of 100 points within the habitat using Hawth's Analysis Tools for ArcGIS.

Economic values for habitat areas were presented graphically in dollars per acre per year $\left(\$ / \mathrm{acre}^{-1} / \mathrm{y}^{-1}\right)$ or dollars per acre $\left(\$ /\right.$ acre $\left.^{-1}\right)$, as these are the units commonly used to measure the value of land in the U.S. Per hectare values are supplied in brackets for comparison with other literature. Values displayed in the maps were rounded to the nearest U.S. $\$ 100$ to avoid unwarranted precision in the estimates.

\section{Yaquina Bay}

For commercial oyster production and recreational clamming harvest, the proportion of the fishery in a given area was known and mapping (using method 1) was relatively straightforward. In Yaquina Bay the oyster harvest, which is strictly commercial, is carried out on plats leased from the Department of State Lands (DSL). Maps of the leased areas were obtained from DSL, and $100 \%$ of the commercial oyster value was attributed to these areas.

Recent survey work conducted by the Oregon Department of Fish and Wildlife (ODFW, unpublished data) quantified clamming effort in each of the major tide flats of Yaquina Bay. The number of clammers per tide flat multiplied by the recreational WTP per tideflat user (Carlson and Fujimoto 2001) resulted in a spatially explicit WTP per tideflat. The location of the clamming effort was further constrained by assuming that all clamming 
was confined to known areas of clam distribution (mapped by Hancock et al. 1979). Because clamming effort was reported for specific tide flats, mean values for each habitat were obtained by random sampling using Hawth's Tools. The clamstock value maps were produced by overlaying published clam-distribution maps for individual clams stocks (Hancock et al. 1979) by their economic values.

For the Dungeness crab fisheries in Yaquina Bay, no data were available on the proportion of the fishery in a given area, so the relative habitat usage method (method 2) was employed. As we found no habitat-specific data on the distribution of Dungeness crab in the Yaquina Bay estuary, we used a study conducted in another U.S. Pacific Northwest estuary, Willapa Bay, Washington (Holsman et al. 2006). Holsman et al. reported a habitat selectivity index for Dungeness crabs for five habitat types in Willapa Bay: eelgrass, unvegetated littoral habitat (ULH), oyster, stake (oyster culture), and sublittoral. Given that oyster culture in Yaquina Bay is primarily subtidal, which is not the case in Willapa Bay, we used the habitat-selectivity indices reported to ascribe relative values to eelgrass, ULH and sublittoral habitat, writing equation 1 as follows:

$\mathrm{EV}_{\text {DUNGENESS CRAB }}=\left(\mathrm{EV}_{U L H} x A_{\mathrm{ULH}}\right)+\left(\mathrm{EV}_{\mathrm{EEL}} \mathrm{x}\right.$ $\left.A_{E E L}\right)+\left(E_{\text {SUB }} x A_{S U B}\right)$

Note that ULH, EEL, and SUB represent unvegetated littoral habitat, eelgrass, and subtidal habitats respectively. The values for the selectivity indices for each habitat type were taken from Holsman et al. 2006, and expressed relative to the ULH habitat-selectivity index and inserted into equation 1 as follows:

$\mathrm{EV}_{\text {DUNGENESS CRAB }}=\left(\mathrm{EV}_{U L H} x A_{\mathrm{ULH}}\right)+\left(0.4 \times \mathrm{EV}_{U L H}\right.$
$\left.x A_{\mathrm{EEL}}\right)+\left(4 \times \mathrm{EV}_{U L H} x A_{\mathrm{SUB}}\right)$

The equation was rearranged to solve for $E V_{U L H}$ and this was used to calculate habitat values for each habitat type.

No habitat-specific salmon fishery information was found for Yaquina Bay or any other U.S. Pacific Northwest estuary. Therefore, each habitat was assumed to contribute equally to the RCFV.

\section{Lagoon Pond}

As no data on the distribution of the recreational and commercial scallop fisheries in Lagoon Pond were available, habitat-affiliation data (EPA, unpublished data) were used to estimate the relative value of different depth bins (0-1 m, 1-2 m, 2-3 m and > m) in Lagoon Pond as scallop habitat (method 2):

$\mathrm{EV}_{\text {SCALLOP }}=\left(\mathrm{EV}_{0-1} \mathrm{x} \mathrm{A}_{0-1}\right)+\left(0.23 \times \mathrm{EV}_{0-1} \mathrm{x} \mathrm{A}_{1-}\right.$ $\left.{ }_{2}\right)+\left(0.09 \times \mathrm{EV}_{0-1} \times \mathrm{A}_{2-3}\right)+\left(0.18 \times \mathrm{EV}_{0-1} \times \mathrm{A}_{>3}\right)$

Note that the subscripts represent each of the four depth bins.

\section{Weeks Bay}

Relative abundance data (EPA, unpublished data) for spotted trout and red drum in Weeks Bay were used to assign values to the three major habitat types in Weeks Bay: ***salt marsh rush (Juncus roemerianus), ***s smooth cord grass (Spartina alterniflora), and unvegetated sublittoral habitats (USL) using method 2:

$\mathrm{EV}_{\mathrm{REC}}=\left(\mathrm{EV}_{\mathrm{JUNCUS}} \times \mathrm{A}_{\mathrm{JUNCUS}}\right)+\left(1.27 \times \mathrm{EV}_{\mathrm{JUNCUS}}\right.$ $\left.x A_{\text {SPARTINA }}\right)+\left(0.09 \times E_{\text {JUNCUS }} \times A_{\text {USL }}\right)$

Economic values from the habitat-based blue crab fisheries-production model were partitioned according to habitat using relative abundance values (EPA, unpublished data) for blue crab in each habitat type:

$\mathrm{EV}_{\text {BLUECRAB }}=\left(\mathrm{EV}_{\text {JUNCUS }} \mathrm{x} \mathrm{A}_{\text {JUNCUS }}\right)+(0.38 \mathrm{x}$ $\left.\mathrm{EV}_{\text {JUNCUS }} \times \mathrm{A}_{\text {SPARTINA }}\right)+\left(0.08 \times \mathrm{EV}_{\text {JUNCUS }} \times \mathrm{A}_{\text {USL }}\right)$

\section{RESULTS}

Table 3 summarizes the results of the economic analysis, along with a qualitative analysis of error in each estimate. Total RCFV was highest in Yaquina Bay (U.S.\$1.8 million-2.9 million), and in the same order of magnitude for Lagoon Pond (U. S.\$1.63 million). For Weeks Bay, RCFV was substantially smaller at U.S.\$94,000. Recreational fisheries were more valuable in each of the estuaries than the commercial fisheries. In Lagoon Pond and Weeks Bay the commercial fisheries constituted 1\% and $2 \%$ of recreational value, whereas in Yaquina 
Bay the major commercial fisheries were between $12 \%$ and $26 \%$ of the recreational-fisheries values.

The most valuable single recreational fishery was the scallop fishery in Lagoon Pond (U.S.\$1.6 million), and this was followed by the recreational fishery for salmon and Dungeness crab in Yaquina Bay, at U.S.\$0.5 million-U.S.\$1.2 million and U.S. $\$ 0.91$ million, respectively.

Figures $3 a$ and $3 b$ show the respective values of recreational clam digging and clams stocks for Yaquina Bay. These maps highlight how mapping of ecosystem services is highly dependent on the definition of the service being used. The distribution of recreational clam digging in the Bay shows a distinct decrease from west to east, reflecting the ease of accessibility to mudflats in the western part of the estuary. In contrast, the stocks of clams are patchily distributed with particularly valuable stocks being located toward the mouth of the estuary as well as in areas less well utilized for clam digging.

Figures 4, 5 and 6 illustrate the spatial distribution of RCFV in Yaquina Bay, Lagoon Pond, and Weeks Bay. Table 4 shows the habitat values associated with each habitat type in each estuary. There was considerable variation in habitat values between estuaries, and these habitat values did not exhibit the same pattern as the overall total RCFV between estuaries. Whereas the shallower waters of Lagoon Pond $(0-1 \mathrm{~m})$ were the most valuable of all our habitat types ( U.S. $\$ 12,000 / \mathrm{acre}^{-1} / \mathrm{yr}^{-1}$ or $\sim$ U.S. $\$ 30,000 \mathrm{ha}^{-1 /} \mathrm{yr}^{-1}$ ), the second-most valuable ( U.S. $\$ 9,000 / \mathrm{acre}^{-1 /} \mathrm{yr}^{-1}$ or $\sim$ U.S.22,000/ha ${ }^{-1} / \mathrm{yr}^{-1}$ ) was the Spartina fringe marsh in Weeks Bay, which had the lowest total RCFV. The high value of the Spartina marsh was because of the high relative abundance of blue crab, spotted trout, and red drum in the habitat, combined with the small total area of the habitat. Both Spartina and Juncus ( U.S. $\$ 6,000 /$ $\mathrm{acre}^{-1} / \mathrm{yr}^{-1}$ or U.S. $\left.\$ 12,500 / \mathrm{ha}^{-1} / \mathrm{yr}^{-1}\right)$ marshes had values three orders of magnitude greater than in the

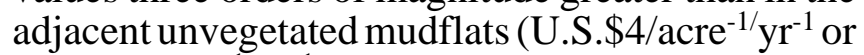
$\sim$ U.S. $\left.\$ 10 / \mathrm{ha}^{-1} / \mathrm{yr}^{-1}\right)$. These were the least valuable of all habitats within the study, resulting in abrupt changes in habitat value over relatively small spatial scales.

Similar abrupt changes in value over small spatial scales were apparent in Yaquina Bay. Here, some intertidal areas having values $<$ U.S. $\$ 600 / \mathrm{acre}^{-1} / \mathrm{yr}^{-1}$ (U.S.\$1,500\&/ha-1/yr-1) were situated directly adjacent to areas with values >U.S.\$1,000/acre $\mathrm{ar}^{-1}$ $\mathrm{yr}^{-1}$ (U.S.\$2,500/ha-1/yr ${ }^{-1}$ ). Maximum values (U.S. $\$ 1,270 / \mathrm{acre}^{-1} / \mathrm{yr}^{-1}$ or U.S.\$3.2 $\mathrm{ha}^{-1} / \mathrm{yr}^{-1}$ ) were observed in the commercial oyster-growing areas in the mid-estuary, closely followed by intertidal areas of heavy recreational clam digging toward the mouth of the estuary (U.S. $\$ 1,300 /$ acre $\mathrm{yr}^{-1} / \mathrm{acre}^{-1} /$ $\mathrm{yr}^{-1}$ or U.S. $\$ 3,100 / \mathrm{ha}^{-1} / \mathrm{yr}^{-1}$ ). The lowest values (U. S. $\$ 500 / \mathrm{acre}^{-1} / \mathrm{yr}^{-1}$ or U.S. $\$ 1,300 \mathrm{ha}^{-1} / \mathrm{yr}^{-1}$ ) were observed in the intertidal eelgrass beds and bare intertidal areas, particularly in the flats of the north shore where clamming effort was low.

\section{DISCUSSION}

Our approach represents a simple and uniform method for rendering economic values spatially explicit. The resulting maps provide a means for decision makers to assess the tradeoffs involved in policies or actions that involve the use of estuarine habitats or coastal land that cause loss of habitats or changes from one habitat type to another, e.g., the drainage of emergent marsh for agriculture or development, or conversion of seagrass habitat to bare mud because of reductions in water quality. Our work indicates the feasibility and utility of the habitat template in mapping estuarine ecosystem service values. Our maps highlight the large differences in the value of estuarine habitat types over fine spatial scales. Mapping these different values is an important step toward efficiently managing our estuarine resources and optimizing the benefits we can obtain from them.

In the three estuaries studied, the producer surplus of commercial fisheries made up a small fraction $(1 \%-26 \%)$ of the consumer surplus resulting from recreational fisheries. This suggests that prioritizing considerations of recreational fisheries in planning decisions involving estuarine habitat might be more beneficial than focusing on the benefits obtained by commercial fishing. Given the nonmarket nature of the recreational consumer surplus, these recreational benefits can easily be overlooked if economic considerations are purely market-based.

We have taken a careful and coherent approach to the valuation exercise. Consumer and producer surplus represent the benefits obtained by recreational and commercial users of the estuaries and, as such, are well aligned with the MEA definition of ecosystem services as benefits. Although many studies have included local economic impacts (e.g., Hazen and Sawyer 2008, 
Table 3. Summary of results of the economic valuation study in each of the three estuaries with estimates of confidence in the data source.

\begin{tabular}{|c|c|c|c|c|c|c|}
\hline \multicolumn{7}{|l|}{ Estuary } \\
\hline \multirow[t]{2}{*}{ Fishery } & \multicolumn{3}{|c|}{ Recreational } & \multicolumn{2}{|c|}{ Commercial } & \multirow{2}{*}{$\begin{array}{c}\text { Total RCFV } \\
\$ / \text { year }^{-1}\end{array}$} \\
\hline & $\begin{array}{l}\text { Value } \\
\text { \$/year }\end{array}$ & $\begin{array}{c}\text { WTP } \\
\text { confidence }\end{array}$ & $\begin{array}{c}\text { NOI } \\
\text { confidence }\end{array}$ & $\begin{array}{l}\text { Value } \\
\text { \$/year }^{-1}\end{array}$ & $\underset{\%}{\text { Standard error }}$ & \\
\hline \multicolumn{7}{|l|}{ Yaquina Bay } \\
\hline salmon & $\begin{array}{l}520,835- \\
1,241,852\end{array}$ & high & low & $0-418,164$ & 23 & \\
\hline bay clams & 142,457 & low & high & & & \\
\hline $\begin{array}{l}\text { Dungeness crab } \\
\text { - within estuary } \\
\text { - ocean fishery }\end{array}$ & $\begin{array}{c}914,173 \\
-\end{array}$ & high & high & $\begin{array}{c}1,909 \\
23,118\end{array}$ & $\begin{array}{l}30 \\
\text { low }\end{array}$ & \\
\hline \multirow[t]{3}{*}{ oyster } & & & & 162,537 & 7 & \\
\hline & & & & & & $2,905,210_{(\max )}$ \\
\hline & & & & & & $1,765,029_{(\min )}$ \\
\hline \multicolumn{7}{|l|}{ Lagoon Pond } \\
\hline \multirow[t]{2}{*}{ bay scallops } & $1,616,963$ & low & low & 13,751 & 23 & \\
\hline & & & & & & $1,630,714$ \\
\hline \multicolumn{7}{|l|}{ Weeks Bay } \\
\hline $\begin{array}{l}\text { spotted trout/ } \\
\text { red drum }\end{array}$ & 85,323 & low & low & - & - & \\
\hline \multirow[t]{2}{*}{ blue crab } & - & - & - & 8,928 & low & \\
\hline & & & & & & 94,251 \\
\hline
\end{tabular}

Note: WTP=Willingness to Pay; NOI=Number of Individuals; RCFV=Recreational and Commercial Fishing Value. Maximum and minimum values are presented for salmon and total RCFV in Yaquina Bay.

Kroeger and McMurray 2008), focusing on benefits and excluding local economic impacts (costs) of the fisheries provides a logically robust basis for intercomparable economic analysis of different estuarine systems. However, the habitat values from our study are consequently lower than in studies that have included recreational expenditure. For example, our mean eelgrass value (U.S.\$590/acre/ $\mathrm{yr}^{-1}$ or U.S. $\$ 1,475 / \mathrm{ha}^{-\mathrm{yr}^{-1}}$ ) represents only a fraction of the U.S. $\$ 4,600$ acre/yr ${ }^{-1}$ (U.S. $\$ 11,500 / \mathrm{ha} / \mathrm{yr}^{-1}$ ) obtained for recreational and commercial fisheries in Indian River Lagoon, Florida (Hazen and Sawyer 2008). Nevertheless, our estimates more accurately reflect ecosystem service values, as opposed to the economic impacts of the estuaries.

Our maps show abrupt changes in ecosystem service values over small spatial scales in estuaries on each 
Fig. 3. (A) Current distribution of recreational clam-digging value (Oregon Department of Fish and Wildlife, unpublished data). (B) Distribution of clam density and potential exploitation (adapted from Hancock et al. 1979).
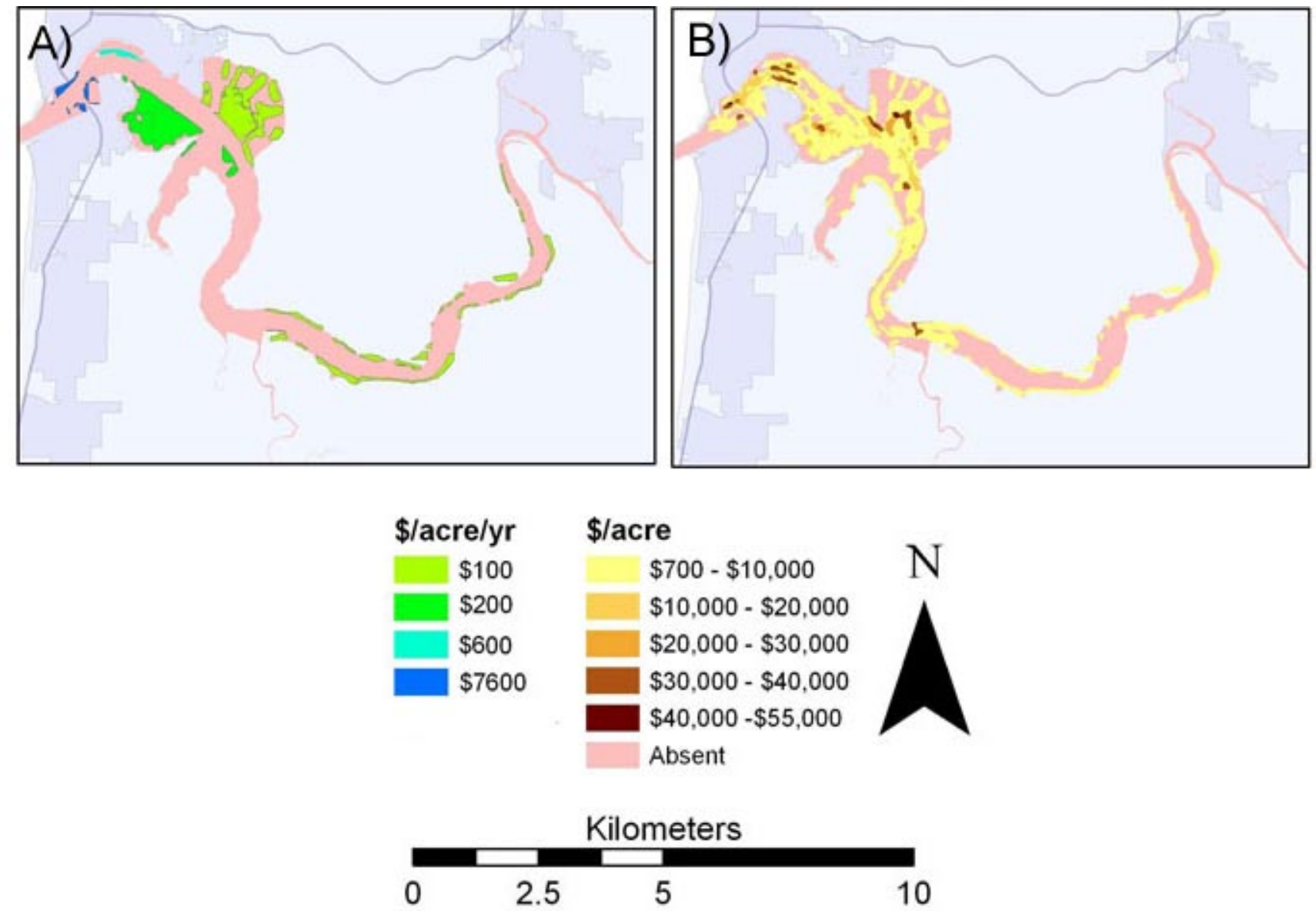

Note: For per-hectare values, multiply by 2.5 .

(A): The number of individuals engaged in recreational clamming was multiplied by a daily beach-use Willingness to Pay form (Carlson and Fujimoto 2001). Values were rounded to the nearest U.S.\$100.

(B): Original data were reported as abundances $>1 \mathrm{ft}^{-2}$ and $>5 \mathrm{ft}^{-2}$. This map was produced by georeferencing the original data and overlaying layers for Gaper, Bentnose, Littleneck, Softshell, Butter, and Cockle. Abundance were assumed to be $1 \mathrm{ft}^{-2}$ and $5 \mathrm{ft}^{2}$, and data were converted to $-\mathrm{m}^{2}$. 
Fig. 4. Distribution of fisheries service values in the Yaquina estuary.

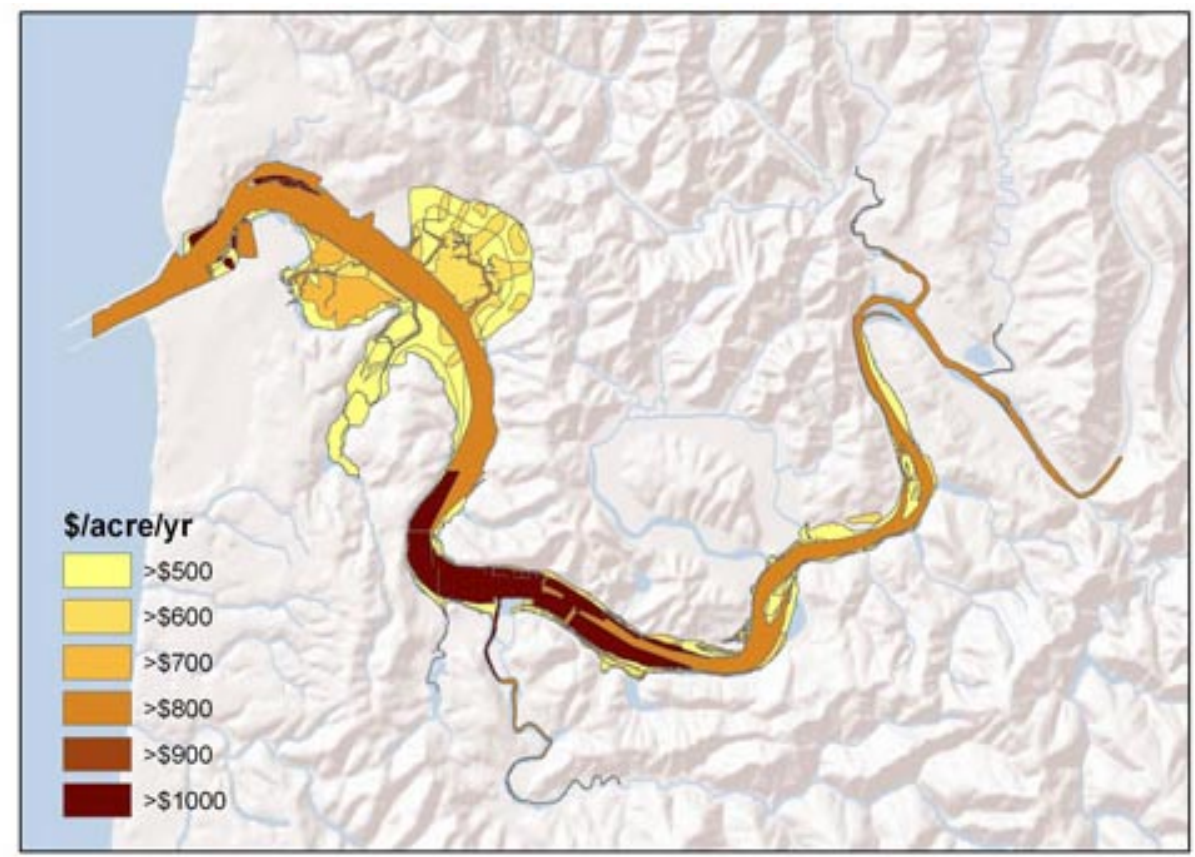

Note: This map is a composite of the commercial oyster map, recreational clamming-effort map, Dungeness crab habitat-preference map, and a salmon value map undifferentiated by habitat type. For per-hectare values, multiply by 2.5 .

coast of the U.S. These rapid changes in economic value over small spatial scales indicate the importance of accounting for fine-scale spatial variability in the ecosystem approach to management, and support the use of the habitattemplate approach as an appropriate method for analyzing development decisions in estuaries.

The high value of the Spartina and Juncus fringe marsh habitats in Weeks Bay was because of their small acreage and high faunal abundance relative to the large less unvegetated area with lower faunal abundance. Similarly, the high values per acre for the shallower habitats in Lagoon Pond were because of the high predicted WTP for recreational fisheries and the small area of the habitats. Although the combined fisheries values for Yaquina Bay were the largest in our work, values per acre were lowest. These low values result from the relatively large area of the estuarine habitats in the bay. This result is similar to the finding of Woodward and Wui (2001) whose meta-analysis showed that wetland value per unit area decreased with the size of the wetland.

Our method does not estimate marginal value of a unit of a particular habitat type, i.e., value lost or gained by removal or addition of a unit area of habitat type. The marginal values of habitat types may vary because of biological and/or social factors. If the area of a nursery habitat is limiting to recruitment or survival of a particular species or the practice of fishing, then the values we have reported for our habitat types might approximate marginal values, as removal of a unit of habitat might result in a corresponding loss of animals. However, if there is some redundancy in the amount of habitat relative to the fishery or recruitment of a given species, our 
Fig. 5. Distribution of ecosystem service habitat value of bay scallop commercial and recreational fisheries based on depth distribution and interpolated bathymetry.

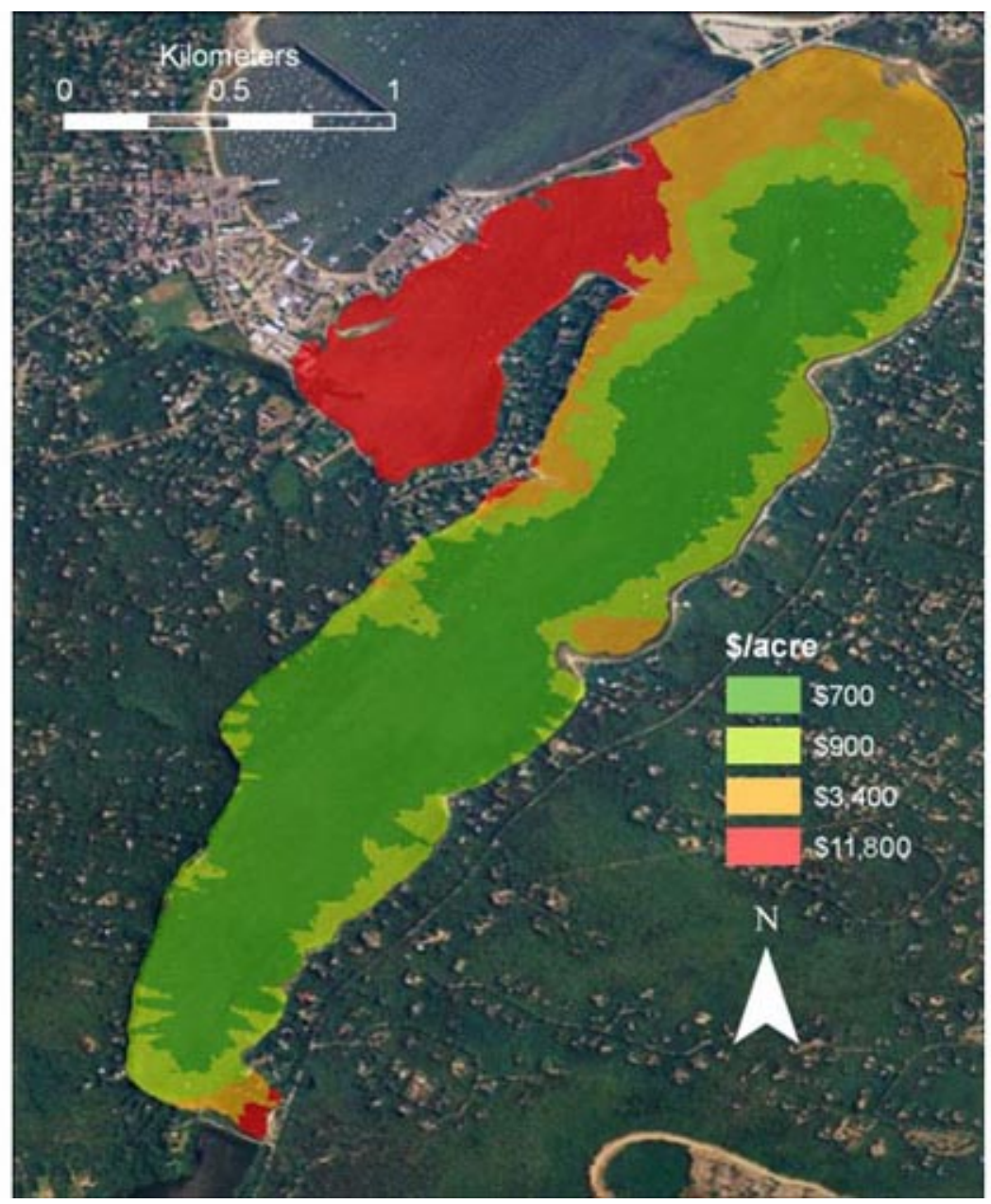

Note: Values are rounded to the nearest $\$ 100$. For per-hectare values, multiply by 2.5 .

values do not represent marginal values. Similarly, reductions in recreational catch caused by habitat loss might also affect WTP (a social phenomenon) for a day of recreation; however, without original economic studies for a given case study, the variability of WTP with changes in the area of habitat remain unknown. In practice, to examine the effect of marginal habitat loss on a fish species or a fishery would require controlled studies of habitat loss and fishery values over time. To this end, the use of habitat-specific production models such as the blue crab model used in our analysis (Jordan et al. 2009) may provide a substitute where observational data are not available.

The diverse array of benefits provided by ecosystems, the differing methods required to measure these benefits, and the bundled nature of the services produced by ecosystems, result in a complex tangle of economic means and ends (Costanza 2008). This complexity has led to debate over the best ways to characterize and quantify these benefits (Boyd and Banzhaf 2007, Wallace 2007). Our Yaquina Bay clamming example provides an 
Fig. 6. Combined map of the commercial and recreational fisheries habitat value of three habitat types in Weeks Bay, Alabama.

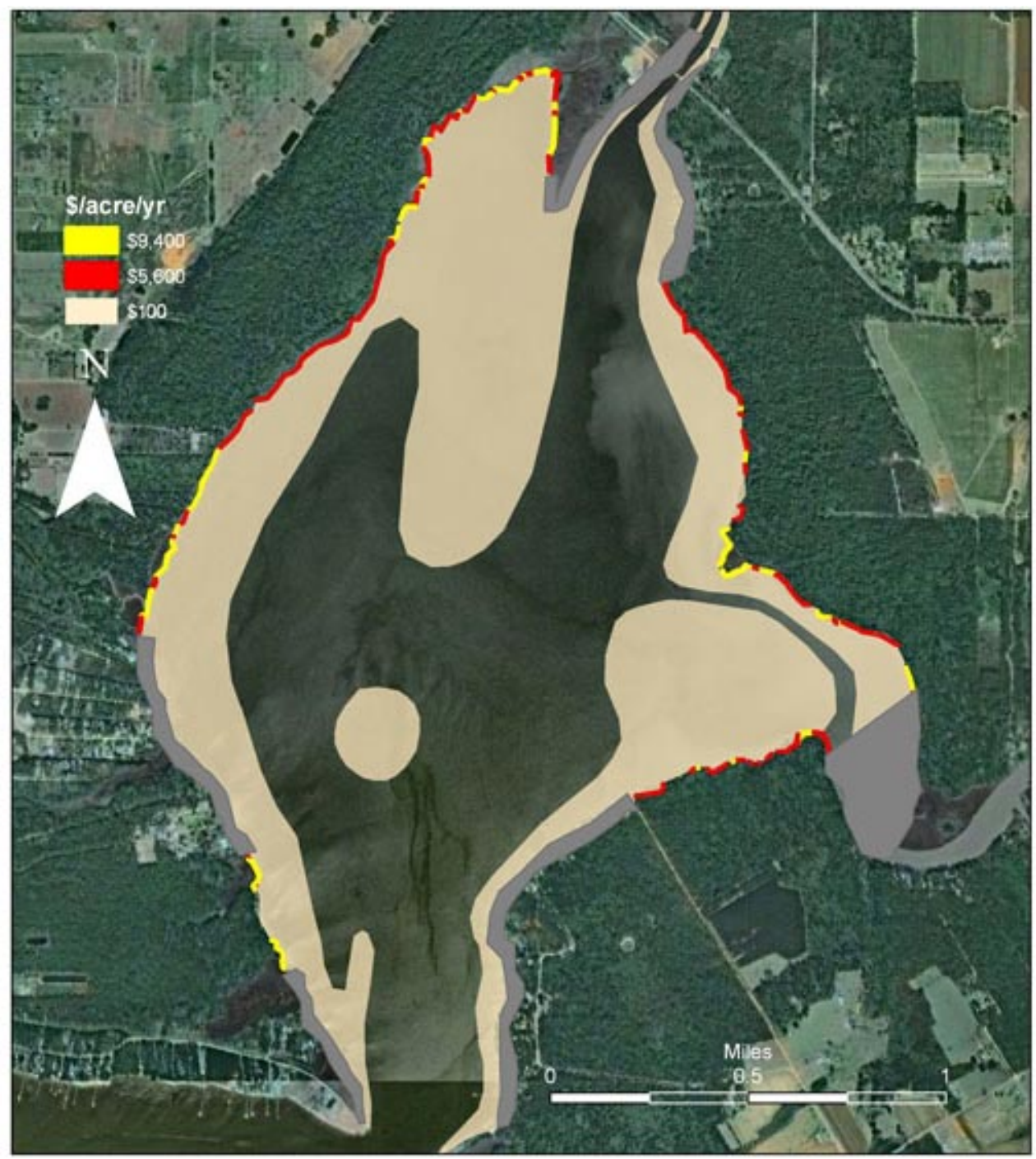

Note: Juncus roemerianus=red. Spartina alterniflora=yellow. Unvegetated sublittoral habitat=beige. Grey areas mark developed shorelines not included in the habitat study. Values are rounded to the nearest $\$ 100$. For per hectare values multiply by 2.5 . 
Table 4. Summary of habitat values for each estuary showing total contribution of RCFV from each habitat type in each estuary.

\begin{tabular}{|c|c|c|c|c|c|}
\hline & Habitat & $\begin{array}{c}\text { Value } \\
\left(\$ / \text { acre }^{-1} / \mathrm{yr}^{-1}\right)\end{array}$ & $\begin{array}{l}\text { Area } \\
\text { (acre) }\end{array}$ & $\begin{array}{l}\text { Habitat total } \\
\qquad\left(\$ / \mathrm{yr}^{-1}\right)\end{array}$ & $\begin{array}{l}\text { Estuary total } \\
\qquad\left(\$ / \mathrm{yr}^{-1}\right)\end{array}$ \\
\hline \multirow[t]{4}{*}{ Yaquina Bay } & subtidal & $\$ 1,000$ & 1884 & $\$ 1,884,100$ & \\
\hline & intertidal & $\$ 700$ & 1,042 & $\$ 729,700$ & \\
\hline & eelgrass & $\$ 600$ & 584 & $\$ 350,237$ & \\
\hline & & & & & $\$ 2,964,000$ \\
\hline \multicolumn{6}{|l|}{ Lagoon Pond } \\
\hline & $0-1 \mathrm{~m}$ deep & $\$ 700$ & 276 & $\$ 193,200$ & \\
\hline & $1-2 \mathrm{~m}$ deep & $\$ 900$ & 105 & $\$ 94,500$ & \\
\hline & 2-3 m deep & $\$ 3,400$ & 74 & $\$ 251,600$ & \\
\hline & $>3 \mathrm{~m}$ deep & $\$ 11,700$ & 93 & $\$ 1,088,100$ & \\
\hline & & & & & $\$ 1,627,400$ \\
\hline \multicolumn{6}{|l|}{ Weeks Bay } \\
\hline & Juncus & $\$ 5,600$ & 8 & $\$ 43,400$ & \\
\hline & Spartina & $\$ 9,400$ & 5 & $\$ 47,600$ & \\
\hline & unvegetated & $\$ 0$ & 819 & $\$ 0$ & \\
\hline & & & & & $\$ 91,100$ \\
\hline
\end{tabular}

Note: All values rounded to the nearest $\$ 100$. Totals may not be exact because of rounding.

excellent illustration of how the spatial distribution of human-use values differs from the spatial distribution of natural stocks, and how differing interpretations of the ecosystem framework result in different spatial apportioning of value. Mapping the distribution of the clam stocks (Fig. 3a) represents a biological reality and may also scale with other ecosystem services such as nutrient cycling or carbon sequestration; however, the distribution of a the fishery-use values of a stock does not necessarily scale with the distribution of a stock itself. Mapping is not necessarily a valueneutral activity. Maps are arguments (Wood and Fels 2008), and mapping the location of valuable and potentially extractable resources can inadvertently make the argument that the resources are there to be extracted, and perhaps distract from the distribution of the use values of a stock. In contrast, mapping the Willingness to Pay for recreational fisheries gives us indication of how humans are using the system. In the case of Yaquina Bay, the most used areas were those closest to the town of Newport, with easy road access as well as abundant clams, whereas clam stocks in the more remote areas remained relatively unexploited (Fig. $3 b)$. This suggests that improved access to a recreational amenity might help maximize the benefit obtained from the estuary. 
A critical issue for us was the availability of data and our dependence on benefit transfer. We relied on personal communications and unpublished data to assess the NOI involved in the recreational fisheries. Benefit transfer was also required to assess WTP in five out of six of our recreational value estimates and, in the case of Weeks Bay, both our estimate of NOI taking part in recreational fisheries as well as the WTP for recreational fisheries at the site. Other authors have pointed to the paucity of, and variability in quality and transferability of, nonmarket valuation data (Woodward and Wui 2001, Brander et al. 2006, Pendleton 2007). This paucity of data is of particular concern given the apparent dominance of the recreational value over commercial value in determining the economic importance of the estuary as a whole. Dependence on benefit transfer introduces unquantified uncertainty into our analysis and reduces the reliability of the data. This becomes particularly problematic when attempting to combine the less error-prone commercial data and to render the combined values spatially.

Habitat maps, combined with habitat faunal associations, allowed us to render economic benefits of fisheries spatially explicit in our three case-study estuaries. To accurately assess habitat values for individual species, habitat-production models are necessary, and consideration must be given to ontogenic shifts in habitat-faunal relations if habitat values are to be assigned correctly. In addition, different habitats may contribute ecologically to the persistence and functioning of other habitats, and these interconnections are not shown in our mapping results, which relied on a simple additive model. In complex ecosystems, the whole may act as more than the sum of its parts. The spatial distribution of habitats is not the only determinant of the spatial distribution of values. Our monetized map of clamming effort in Yaquina Bay (Fig. $3 b$ ) indicates that human usage patterns depend on existing built capital structures. The difference in economic values between estuaries indicates that monetary value is also dependent on local demographics. The spatial distribution of ecosystem service values in estuaries is a complex function of local fisheries productivity, human behavior, and demography.
Responses to this article can be read online at:

http://www.ecologyandsociety.org/voll5/iss4/art7/responses/

\section{Acknowledgments:}

The authors would like to thank Mitch Vance and Justin Ainsworth of the Oregon Department of Fish and Wildlife; Gil Sylvia of Oregon State University; Pat Clinton, Matt Weber and Walt Nelson of the U. S. Environmental Protection Agency; National Research Council associateship program staff; the ladies of the Marilyn Potts Guinn Library; Dave Grunden; and Scott Phipps. Thanks to the two anonymous reviewers. Particular thanks to Marissa Mazzotta and Mark Russell for helpful and insightful comments.

\section{LITERATURE CITED}

Agardy, T., J. Alder, N. Ash, R. DeFries, and G Nelson. 2005. Synthesis: condition and trends in systems and services, trade-offs for human wellbeing, and implications for the future. Pages 823834 in: R. Hassan, R. Scholes, and N. Ash, editors. Ecosystems and human well-being: current state and trends: findings of the Condition and Trends Working Group. Island Press, Washington, D.C., USA.

Amaral, V., H. N. Cabral, S. Jenkins, S. Hawkins, and J. Paula. 2009. Comparing quality of estuarine and nearshore intertidal habitats for Carcinus maenas. Estuarine Coastal and Shelf Science 83:219-226.

Armstrong, D. A., C. Rooper, and D. Gunderson. 2003. Estuarine production of juvenile Dungeness Crab (Cancer magister) and contribution to the Oregon-Washington coastal fishery. Estuaries 26: 1174-1188.

Bishop, J., S. Kapila, F. Hicks, P. Mitchell, and F. Vorhies. 2008. Building biodiversity business. Shell International Limited and the International Union for Conservation of Nature (IUCN), London, UK, and Gland, Switzerland.

Boumans, R., R. Costanza, J. Farley, M. A. 
Wilson, R. Portela, J. Rotmans, F. Villa, and M. Grasso. 2002. Modeling the dynamics of the integrated earth system and the value of global ecosystem services using the GUMBO model. Ecological Economics 41:529-560.

Boyd, J., and S. Banzhaf. 2007. What are ecosystem services? The need for standardized environmental accounting units. Ecological Economics 63:616-626.

Brander, L., R. Florax, and J. Vermaat. 2006. The empirics of wetland valuation: a comprehensive summary and a meta-analysis of the literature. Environmental and Resource Economics 33:223250 .

Bricker, S., B. Longstaff, W. Dennison, A. Jones, K. Boicourt, C. Wicks, and J. Woerner. 2007. Effects of nutrient enrichment in the nation's estuaries: a decade of change. National Estuarine Eutrophication Assessment Update. National Oceanic and Atmospheric Administration (NOAA) Coastal Ocean Program Decision Analysis Series No. 26. National Centers for Coastal Ocean Science, Silver Spring, Maryland, USA.

Brown, C. A., and R. J. Ozretich. 2009. Coupling between the coastal ocean and Yaquina Bay, Oregon: importance of oceanic inputs relative to other nitrogen sources. Estuaries and Coasts 32:219-237

Carlson, C., and R. W. Fujimoto. 2001. New Carissa recreational loss pre-assessment report. NOAA/USDA. [online] URL: URL:http://www.fws. gov/oregonfwo/Contaminants/Spills/NewCarissa/ RestorationPlan/Documents/NewCarissaDARPApp endix4RecreationalLossReport.pdf

Carman, M. R., K. E. Hoagland, E. Green-Beach, and D. W. Grunden. 2009. Tunicate faunas of two North Atlantic-New England islands: Martha's Vineyard, Massachusetts and Block Island Rhode Island. Aquatic Invasions 4:65-70

Cebrian, J., and I. Valiela. 1999. Seasonal patterns in phytoplankton biomass in coastal ecosystems. Journal of Plankton Research 21:429-444

Champ, P. A., K. J. Boyle, and T. C. Brown, editors. 2003. A primer on nonmarket valuation. Kluwer Academic Publishers, Dordrecht, The Netherlands.
Conley, D. J. 1999. Biogeochemical nutrient cycles and nutrient management strategies. Hydrobiologia 410:87-96.

Costanza, R. 2008. Ecosystem services: multiple classification systems are needed. Biological Conservation 141:350-352. [online] URL: http://w ww.sciencedirect.com/science? ob=ArticleURL\& udi $=$ B6V5X-4RPVJ5V-3\& user $=14684 \&$ coverDate $=02 \%$ 2F29\%2F2008\& $\mathrm{rdoc}=1 \& \mathrm{fmt}=$ high \& orig $=$ article \& $\mathrm{cdi}=5798 \&$ sort $=\mathrm{v} \&$ docanchor $=\& \mathrm{view}=$ $\mathrm{c} \& \mathrm{ct}=504 \&$ acct $=\mathrm{C} 000001678 \&$ version $=1 \&$ ur

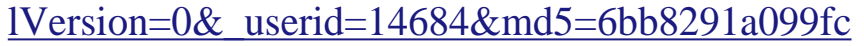
c25b1c8baedf093fb12.

Constanza, R., R. d'Arge, R. deGroot, S. Farber, M. Grasso, B. Hannon, K. Limburg, S. Naeem, R. V. O'Neill, J. Paruelo, G. R. Raskin, P. Sutton, and M. Van den Belt. 1997. The value of the world's ecosystem services and natural capital. Nature 387:253-260

Dahlgren, C. P., T. G. Kellison, A. J. Adams, B. M. Gillanders, M. S. Kendall, C. A. Layman, J. A. Ley, I. Nagelkerken, and J. E. Serafy. 2006. Marine nurseries and effective juvenile habitats: concepts and applications. Marine Ecology Progress Series 312:291-295.

Daily, G. C. 1997. Nature's services: societal dependence on natural ecosystems. Island Press, Washington, D.C., USA.

Daily, G. C., and P. R. Ehrlich. 1999. Managing Earth's ecosystems: an interdisciplinary challenge. Ecosystems 2:277-280.

Daily, G. C., and B. H. Walker. 2000. Seeking the great transition. Nature 403:243-245.

Davis, J. A., F. Hetzel, J. J. Oram, and L. J. McKee. 2007. Polychlorinated biphenyls (PCBs) in San Francisco Bay. Environmental Research 105:67-86.

Ehrlich, P. R., and A. H. Ehrlich. 2008. Nature's economy and the human economy. Environmental Resource Economics 39:9-16.

Endreny, P. A., and G. Sylvia. 2006. Mapping a path to sustainable utilization of Bay Clam Resource in Oregon's 21 st century estuaries: an investigation into the potential of Oregon's bay clam fishery. Report to the Oregon Department of Fish and Wildlife and the Oregon Commercial Bay Clam 
Industry. Corvallis, Oregon, USA.

European Union. 2008. Directive 2008/56/EC of the European Parliament and of the Council of 17 June 2008 establishing a framework for community action in the field of marine environmental policy. Official Journal L 164, 25/06/2008:0019-0040.

Ferraro, S. P., and F. A. Cole. 2004. Optimal benthic macrofaunal sampling protocol for detecting differences among four habitats in Willapa Bay, Washington, USA. Estuaries 27:1010-1025.

Ferraro, S. P., and F. A. Cole. 2007. Benthic macrofauna-habitat associations in Willapa Bay, Washington, USA. Estuarine Coastal and Shelf Science 71:491-507.

Fisher, B., and R. K. Turner. 2008. Ecosystem services: classification for valuation. Biological Conservation 141:1167-1169.

Flegal, A. R., C. L. Brown, S. Squire, J. R. M. Ross, G. M. Scelfo, and S. Hibdon. 2007. Spatial and temporal variations in silver contamination and toxicity in San Francisco Bay. Environmental Research 105:34-52.

Franca, S., M. J. Costa, and H. N. Cabral. 2009. Assessing habitat specific fish assemblages in estuaries along the Portuguese coast. Estuarine Coastal and Shelf Science 83:1-12.

Gaines, A. G. 1986. Lagoon Pond study: an assessment of environmental issues and observations on the estuarine system. Final report for the Town of Oak Bluffs. Woods Hole Oceanographic Institution, Woods Hole, Massachusetts, USA.

Griffin, K. 1995. Identification and distribution of subtidal and intertidal shellfish populations in Tillamook Bay, Oregon. College of Ocean and Atmospheric Science, Oregon State University, Corvallis, Oregon, USA.

Hancock, D. R., T. F. Gaumer, G. B. Willeke, G. P. Robart, and J. Flynn. 1979. Subtidal clam populations: distribution, abundance, and ecology. Oregon State University Sea Grant Program, Oregon State University, Corvallis, Oregon, USA.

Hanna, S., G. Sylvia, M. Harte, and G.
Achterman. 2006. Review of economic literature and recommendations for improving economic data and analysis for managing Columbia River spring chinook. Report to the Oregon Department of Fish and Wildlife, agreement number 005-4132S-Wild. Oregon State University, Corvallis, Oregon, USA.

Hardy, A. 1960. Was man more aquatic in the past? New Scientist 7:642-645.

Hayes, K. M., T. J. Tyrrell, and G. Anderson. 1992. Estimating the benefits of water quality improvements in the Upper Narragansett Bay. Marine Resource Economics 7:75-85.

Hazen and Sawyer. 2008. Indian River lagoon economic assessment and analysis update for the Indian River Lagoon National Estuary Program. Hollywood, Florida, USA. [online] URL: http://ww w.sjrwmd.com/itsyourlagoon/pdfs/IRL Economic Assessment 2007.pdf

Hemminga, M. A., and C. M. Duarte. 2000. Seagrass ecology. Cambridge University Press, Cambridge, UK.

Hickey, B. M., and N. S. Banas. 2003. Oceanography of the U.S. Pacific Northwest coastal ocean and estuaries with application to coastal ecology. Estuaries 26:1010\&\#82111031.

Holsman, K. K., P. S. McDonald, and D. A. Armstrong. 2006. Intertidal migration and habitat use by subadult Dungeness crab Cancer magister in a Northeast Pacific estuary. Marine Ecology Progress Series 308:183-195.

Horrobin, D. 2001. The madness of Adam and Eve: how schizophrenia shaped humanity. Bantam, New York, New York, USA.

Hosack, G. R., B. R. Dumbauld, J. L. Ruesink, and D. A. Armstrong. 2006. Habitat association of estuarine species: comparisons of intertidal mudflat, seagrass (Zostera marina), and oyster (Crassostrea gigas) habitats. Estuaries and Coasts 29:1150-1160.

Howarth, R. W. 1998. An assessment of human influences on fluxes of nitrogen from the terrestrial landscape to the estuaries and continental shelves of the North Atlantic Ocean. Nutrient Cycling in Agroecosystems 52:213-223. 
Huppert, D. D., R. L. Johnson, J. Leahy, and K. Bell. 2003. Interactions between human communities in the Pacific Northwest: trends and implications for management. Estuaries 26:994-1009.

Jackson, E., A. A. Rowden, M. Attrill, S. J. Bossey, and M. B. Jones. 2001. The importance of seagrass beds as a habitat for fishery species. Oceanography and Marine Biology: An Annual Review 39:269-303.1.

Johnston, R. J., T. A. Grigulanus, J. J. Opaluch, M. Mazzotta, and J. Diamantedes. 2002. Valuing estuarine resource services using economical and ecological models: the Peconic estuary system study. Coastal Management 30:47-65.

Jordan, S. J., L. M. Smith, and J. A. Nestlerode. 2009. Cumulative effects of coastal habitat alterations on fishery resources: toward prediction at regional scales. Ecology and Society 14(1): 16. [online] URL: http://www.ecologyandsociety.org/voll4/ iss1/art16/.

Kennett, D. J., and J. P. Kennett. 2006. Early state formation in southern Mesopotamia: sea Levels, shorelines, and climate change. Journal of Island and Coastal Archaeology 1:67-99.

Kroeger, T., and A. McMurray. 2008. Economic benefits of conserving natural lands-case study: Yaquina Bay Conservation Opportunity Area, Oregon. Defenders of Wildlife, Washington, D.C., USA.

Loomis, J., and L. Richardson. 2007. Benefit transfer and visitor use estimating models of wildlife recreation, species and habitats. Department of Agriculture and Resource Economics, Colorado State University, Fort Collins, Colorado, USA. [online] URL: http://dare.colostate.edu/tools/benef ittransfer.aspx.

Lotze, H. K., H. S. Lenihan, B. J. Bourque, R. H. Bradbury, R. G. Cooke, M. C. Kay, S. M. Kidwell, M. X. Kirby, C. H. Peterson, and J. B. C. Jackson. 2006. Depletion, degradation, and recovery potential of estuaries and coastal seas. Science 312:1806-1809.

Marshall, A. 1890. The principles of economics. McMillan, London, UK.
McFarlane, S. L. 1999. Bay scallops in Massachusetts waters: a review of the fishery prospects for future enhancement and aquaculture. Barnstable County's Cape Cod Cooperative Extension, Southern Massachusetts Aquaculture Center, Amherst, Massachusetts, USA. [online] URL: http://www.chilmarkma.gov/Pages/Chilmark MA BBoard/Archived\%20News/FinalScallopReport. pdf.

Millennium Ecosystem Assessment (MEA). 2003. Ecosystems and human well-being: a framework for assessment. Island Press, Washington, D.C., USA.

Millennium Ecosystem Assessment (MEA). 2005. Ecosystems and human well being: Wetlands and water synthesis. World Resources Institute, Washington, D.C., USA.

Nelson, E., G. Mendoza, J. Regetz, S. Polasky, H. Tallis, R.D. Cameron, K. M.A. Chan, G. C. Daily, J. Goldstein, P. Kareiva, E. Lonsdorf, R. Naidoo, T. H. Ricketts, and M. R. Shaw. 2009. Modeling multiple ecosystem services, biodiversity conservation, commodity production, and tradeoffs at landscape scales. Frontiers in Ecology and the Environment 7:4-11. [online] URL: http://dx.doi.org/10.1890/08 $\underline{0023}$.

Nilsson, C., C. A. Reidy, M. Dynesius, and C. Revenga. 2005. Fragmentation and flow regulation of the world's large river systems. Science 308:405408.

Nordhaus, W.. 2008. A question of balance. Yale University Press, New Haven, Connecticut, USA.

Norgaard, R. B., C. Bode, and Values Reading Group. 1998. Next, the value of God, and other reactions. Ecological Economics 25:37-39.

Parrish, J. K., and K. Litle. 2001. Pacific Northwest Coastal Ecosystems Regional Study (PNCERS) 2000 annual report. NOAA, Coastal Ocean Programs, Silver Spring, Maryland, USA.

Pendleton, L., P. Atiyah, and A. Moorthy. 2007. Is the non-market literature adequate to support coastal and marine management? Ocean and Coastal Management 50:363-378.

Richardson, L., and J. Loomis. 2009. The total economic value of threatened, endangered and rare 
species: an updated meta-analysis. Ecological Economics 68:1535-1548.

Ross, D. A. 1995. Introduction to Oceanography. Harper Collins, New York, New York, USA.

Schroeder W., W, S. P. Dinnel, and W. J. Wiseman. 1992. Salinity structure of a shallow, tributary estuary. Pages 155-171 in D. Prandle, editor. Dynamics and exchanges in the coastal zone. Coastal and Estuarine Studies 40. American Geophysical Union, Washington, D.C., USA.

Schroeder W. W., W. J. Wiseman, and S. P. Dinnel. 1990. Wind and river induced fluctuations in a small, shallow tributary estuary. Pages 482-493 in R. T. Cheng, editor. Residual currents and long term transport. Coastal and estuarine studies. Volume 38. American Geophysical Union, Washington, D.C., USA.

Sigleo, A. C., and W. E. Frick. 2007. Seasonal variations in river discharge and nutrient export to a northeastern Pacific estuary. Estuarine Coastal and Shelf Science 73:368-378.

Sigleo, A. C., C. W. Mordy, P. Stabeno, and W. E. Frick. 2005. Nitrate variability along the Oregon coast: estuarine-coastal exchange. Estuarine Coastal and Shelf Science 64:211-222.

Stutes, A. L., J. Cebrian, and A. A. Corcoran. 2006. Effects of nutrient enrichment and shading on sediment primary production and metabolism in eutrophic estuaries. Marine Ecology Progress Series 312:29-43.

Troy, A., and M. A. Wilson. 2006. Mapping ecosystem services: practical challenges and opportunities in linking GISS and value transfer. Ecological Economics 60:435-449.

Tveskov, M. A., and J. M. Erlandson. 2003. The Haynes Inlet weirs: estuarine fishing and archaeological site visibility on the southern Cascadia coast. Journal of Archaeological Science 30:1023-1035.

United States Department of Agriculture (USDA). 2008. 2007-2008 Oregon agriculture and fisheries statistics. USDA National Agricultural Statistics Service, Washington, D.C., USA.

Verhaegan, M., S. Munro, M. Vaneechoutte, N.
Bender-Oser, and R. Bender. 2007. The original econiche of the genus Homo: open plain or waterside? Pages 155-186 in S. I. Munoz, editor. Ecology research progress. Nova Science, Hauppauge, New York, USA.

Verhaegen, M., P. F. Puech, and S. Munro. 2002. Aquarboreal ancestors? Trends in Ecology and Evolution 17:212-217.

Wallace, K. J. 2007. Classification of ecosystem services: problems and solutions. Biological Conservation 139:235-246.

Webster, J. G., and H. Hiveley. 2006. Yaquina Bay bibliography. Oregon State University Libraries, Corvallis, Oregon, USA. [online] URL: http://osuli brary.orst.edu/guin/yaquina-bay-bibliography.

Wilson, M., R. Costanza, R. Boumans, and S. Liu. 2005. Integrated assessment and valuation of ecosystem goods and services provided by coastal systems. Pages 1-24 in J. G. Wilson, editor. The intertidal ecosystem: the value of Ireland's shores. Royal Irish Academy, Dublin, Ireland.

Wood, D., and J. Fels. 2008. The natures of maps: cartographic constructions of the natural world. University of Chicago Press, Chicago, Illinois, USA.

Woodward, R. T., and Y. S. Wui. 2001. The economic value of wetland services: a metaanalysis. Ecological Economics 37:257-270.

Wouters, N., and H. N. Cabral. 2009. Are flatfish nursery grounds richer in benthic prey? Estuarine Coastal and Shelf Science 83(4):613-620. 